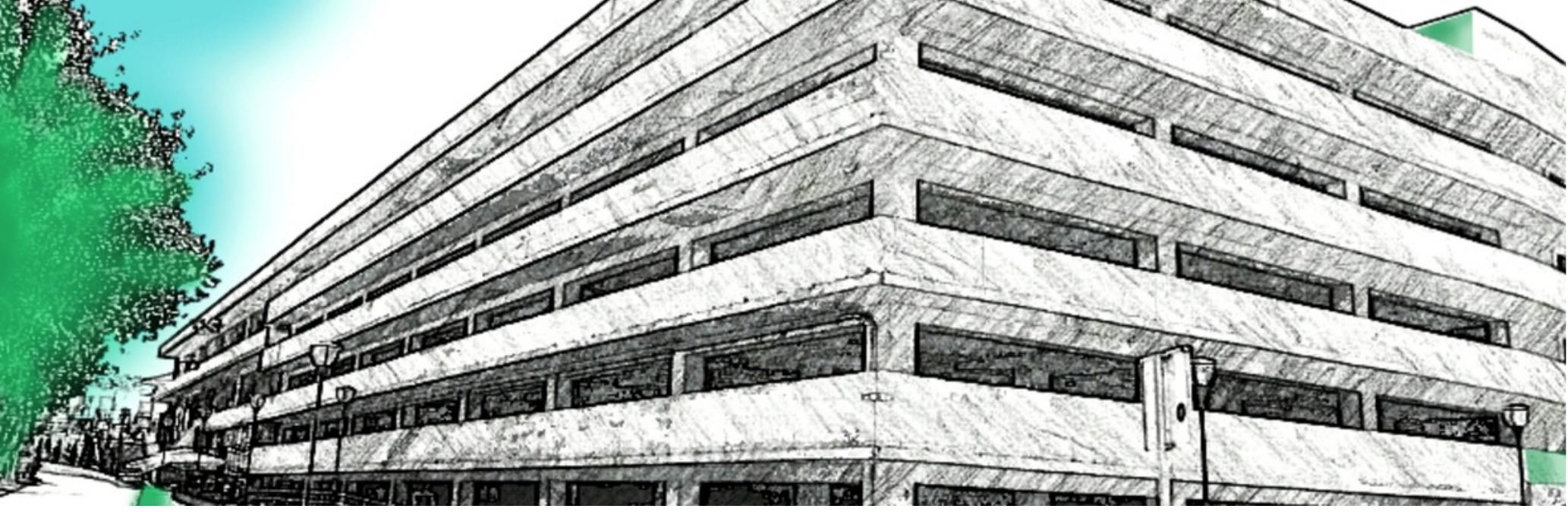

Challenges of Architectural Design in relation to Environment and Air Pollution. A Case study: Prishtina's first public parking garage

Authors: $\quad$ Bujar Q. Bajçinovci

Submitted:

9. November 2016

Published:

13. November 2016

Volume:

Issue:

3

Keywords:

7

DOI:

Architecture, Environment, Air Pollution

10.17160/josha.3.7.254 


\title{
Challenges of Architectural Design in relation to Environment and Air Pollution. A Case study: Prishtina's first public parking garage
}

\author{
Bujar Bajçinovci ${ }^{1}$, Florina Jerliu ${ }^{* 1}$ \\ ${ }^{1}$ University of Prishtina, Faculty of Civil Engineering and Architecture, Kosovo. \\ "Email: florina.jerliu@uni-pr.edu; bujar.bajcinovci@uni-pr.edu
}

\begin{abstract}
Cities are complex ecosystems with specific phenomenon directly reflected in our health, resources, economic, social and aesthetic fields. It can be conceptually considered that cities are locally and regionally specific. Urban planning is a process with a primary role to protect and use of environment, to manage spatial planning and urban infrastructure as a whole system. In relation to sustainability and implementation of multi-level law reinforcement, urban planning and design can significantly improve quality of life of their urbanites, particularly in relation to air pollution. Surely, long-term plans and strategies have been adopted in Kosovo, but the challenges will remain in implementation and in enforcement of these administrative instructions. Therefore, it is crucial to encourage every action, related to city functionality which will minimize air pollution. The new millennium began a crucial activity for the city of Prishtina in terms of demographic and socio-spatial phenomenon's. Prishtina is generally polluted due to its geomorphic position relative to the major polluters, power plants Kosovo A and B. In addition to that, the contamination is even bigger when the dominant winds prevail. The conceptual findings from this research proposes the necessity of careful driven urban solutions, regarding to the location and position of architectural structures which are not necessarily favourable to the urban, economic and health objectives.
\end{abstract}

Keywords: Prishtina, Architecture, Urban planning, Air pollution, Environment, PMxx.

\section{INTRODUCTION}

Cities are complex ecosystems with specific phenomenon's directly reflected in our health, natural resources, economic, social and aesthetic fields. They are open integrated systems and huge organisms with specific and complex metabolism that transform vast amount of energy, generate huge amount of waste and emanate a number of specific environmental phenomenon's and activities. However, it can be conceptually considered that cities are locally and regionally specific, and therefore the specific environmental emanations are certain attributes of each city. Each ecosystem requires a structured and functional activity of its constituent subsystems. Fast growing cities have their own specific emergency needs and also completely new concepts and original challenges. Thus when fast growing cities 
face these challenges, they also face immediate problems, which have to be solved in order to function normally. New challenges should stimulate new research, directed towards the exploitation of all resources, in order to provide a better and higher quality of life. Urban geometry and expansion of city development presents a spatial framework, aiming to achieve a better quality of life for their urbanites, with primary features that affect air quality and health wellbeing. Therefore, urban planning determines the areas, location of urban blocks and architectural structures that can potentially emanate and be air pollutants. According to World Health Organisation, Europe, "The epidemiological and toxicological evidence on the effects of transport related air pollution on health has increased substantially in recent decades. Although this includes epidemiological and toxicological evidence, it is only a fraction of the total evidence on the effects on health of urban air pollution. A review of this evidence indicates that transport related air pollution contributes to an increased risk of death, particularly from cardiopulmonary causes. It increases the risk of respiratory symptoms. "[1].

"Outdoor concentrations of traffic-related air pollutants (nitrogen dioxide $\mathrm{PM}_{2.5}$, particles with a $50 \%$ cut-off aerodynamic diameter of $2.5 \mathrm{~mm}$ and soot) were assigned to birthplace home addresses with a land-use regression model. They were linked by logistic regression to questionnaire data on doctor-diagnosed asthma, bronchitis, influenza and eczema and to self-reported wheeze, dry night-time cough, ear/nose/throat infections and skin rash...Traffic-related pollution was associated with respiratory infections and some measures of asthma and allergy during the first 4 yrs. of life."[2].

Also, in Kosovo, there was study research in the field of air pollution and efficiency of energy, related in emissions of $\mathrm{CO}_{2}$ and Gross Domestic Product, "Kosovo as one of the richest countries with lignite in Europe with $95-97 \%$ of the electric power production from lignite and with $90 \%$ of vehicles over 10 years old, represents one of the regions with the greatest $\mathrm{CO}_{2}$ output per GDP per unit of economic activity, as well as one of the countries with the most polluted atmosphere in Europe. In this relation we must consider the fact that Kosovo is a developing country" [3]. The objective of this paper is to address three dimensions that relate to the Urban Planning in relation to Air Quality, and health impact according to the actual location and distance of open public parking garage to the Clinical Hospital Center campus: 
- Improving the quality of the urban environment and land use.

- The impact of urban growth on demographic changes and traffic problems in the city of Prishtina.

- The need for parking spaces and public parking garages.

While air pollution is obviously a global environmental issue, there is a strong will of the community for sustainable awareness, aiming to live healthier. Municipality of Prishtina have a potential for urban environmental planning, and civil society actions further strengthen this objective permanently.

Hence: Does traffic issue, the need for parking spaces and pattern of future public parking garages of the city of Prishtina, can be worked out with an urban model like, "Public parking garage at Clinical Hospital Centre?

\section{MATERIALS and METHODS}

The study presented in this paper investigated the Ulpiana neighbourhood of Prishtina City, focussing on Urban Planning issues, traffic problems and air pollution. The research methods consist of empirical observation through field, with an accent to the structure of the public parking garage at Clinical Hospital Centre. In order to receive a clearer data and information's, research is made within spatial regulation of urban block, shapes of architectural models, focusing on the bioclimatic features regarding to the morphology of the city of Prishtina, urban planning, environmental pollution, and issues of public health. Case study were investigated through literature review, urban city documentations and drawings developed, "in situ".

Graphic documentation contains photos, handmade drawings of the urban composition and Upliana neighbourhood, accenting to architectural structure and position of the public parking garage at Clinical Hospital Centre, regarding to the city urban composition. The data collected include maps, 3D composition of urban structure, bioclimatic features and attributes of space, dimensions of location and traffic activities.

The additional data for this paper is based on the analysis of the Municipality of Prishtina archives, the Kosovo Institute of Public Health, and the Hydro Meteorological Institute of Kosovo. Measurements are based on the Hydro Meteorological Institute of Kosovo [6], Ministry of Environment and Spatial Planning, monthly report on air quality monitoring [7], Environmental Protection Agency (US), AirNow Department of State [8]. 


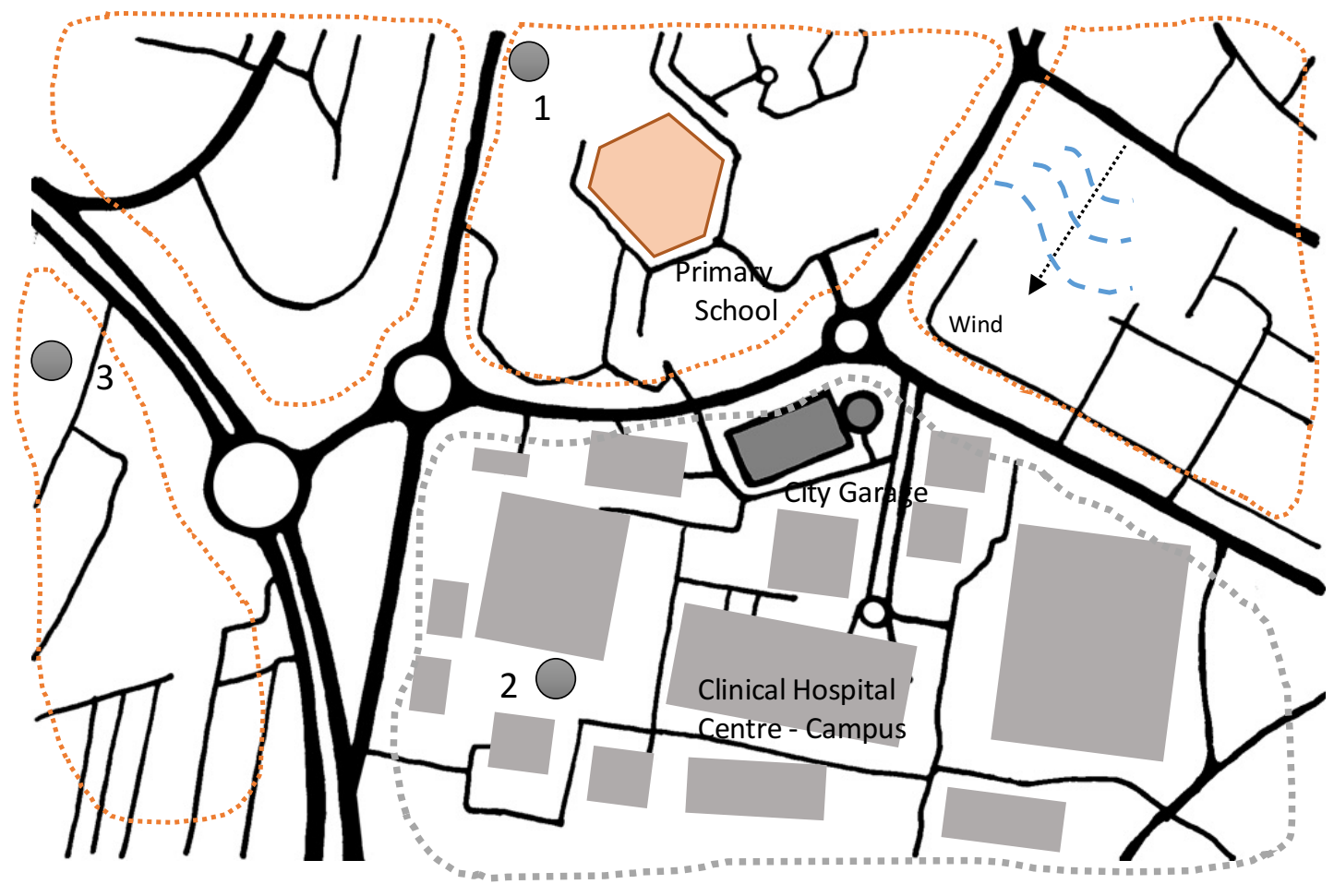

Figure 1. City of Prishtina. Clinical Hospital Centre-Campus. Location of public parking garage, and measurement points of $\mathrm{PM}_{\mathbf{x x}}$ : 1, 2, 3. [Source: Authors, 2016]

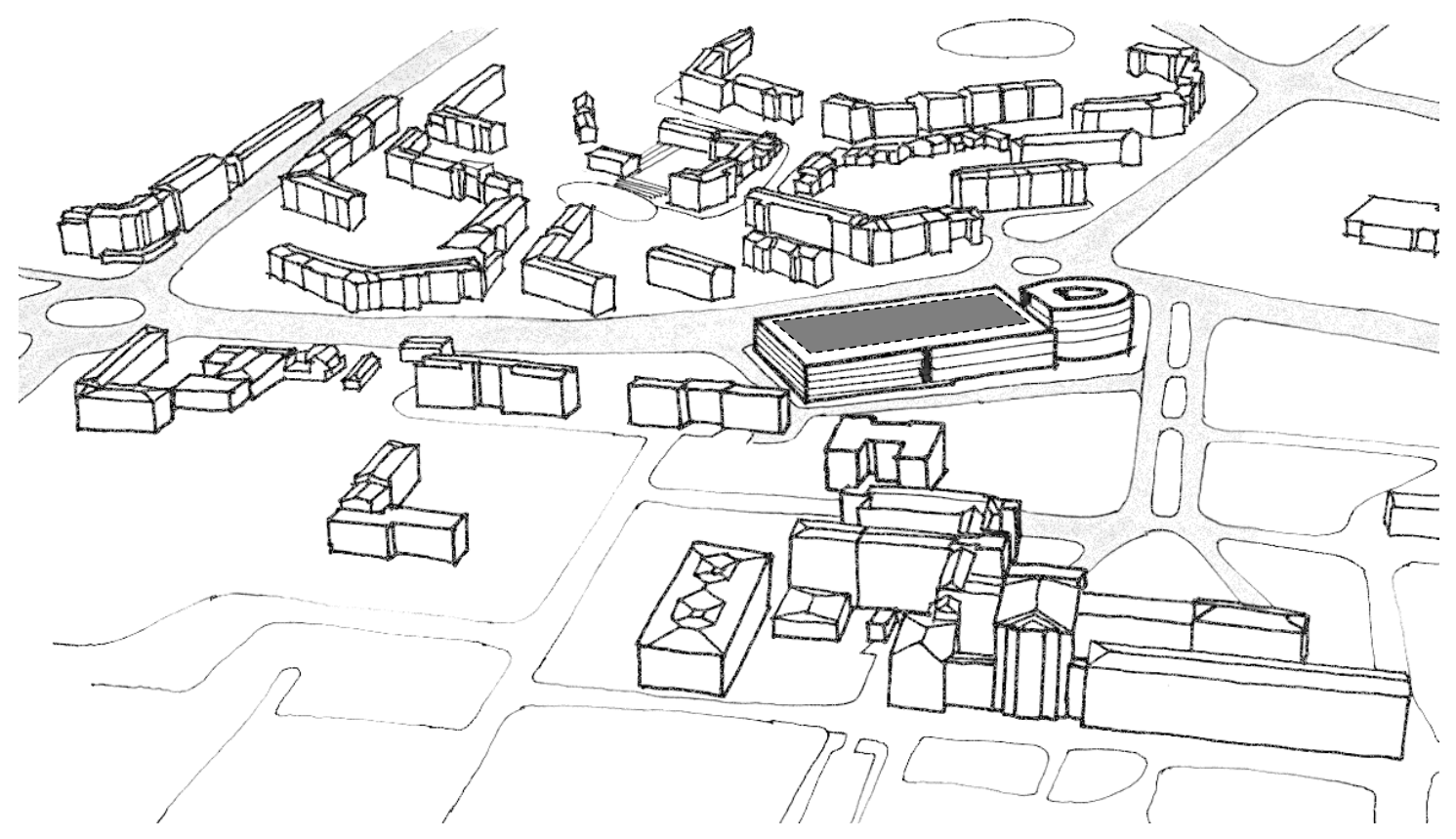

Figure 2. Composition of Urban Structure. Clinical Hospital Centre-Campus, Ulpiana neighbourhood and location of the public parking garage. [Source: Authors, 2016] 
Table 1. Results of $\mathrm{PM}_{2.5},\left(\mu \mathrm{g} / \mathrm{m}^{3}\right)$, measuring Point 2, for 2010. [6]

\begin{tabular}{lcc}
$\mathbf{P M}_{\mathbf{2 . 5}}$ & Max. & Min. \\
\hline November & 148.87 & 26.02 \\
\hline December & 110.2 & 13.73 \\
\hline January & 144.74 & 11.38 \\
\hline February & 110.3 & 10.23 \\
\hline March & 46.61 & 18.93
\end{tabular}

Table 2. Results of $\mathrm{PM}_{10},\left(\mu \mathrm{g} / \mathrm{m}^{3}\right)$, measuring Point 3, for 2010. [6]

\begin{tabular}{lcc} 
PM $_{10}$ & Max. & Min. \\
\hline September & 83.1 & 24.1 \\
\hline October & 128.2 & 10.6 \\
\hline November & 278.6 & 37.97 \\
\hline December & 141.79 & 16.96 \\
\hline January & 155.90 & 14.07 \\
\hline February & 125.98 & 16.05 \\
\hline March & 73.05 & 24.19
\end{tabular}

Table 3. Results of $\mathrm{PM}_{10},\left(\mu \mathrm{g} / \mathrm{m}^{3}\right)$, average values per month, for 2015. [7]

\begin{tabular}{|c|c|c|c|c|c|c|c|c|c|c|c|c|c|}
\hline Month & Jan. & Feb. & Mar. & Apr. & May & Jun & July & Aug. & Sept. & Octo. & Nov. & Dec. & $\begin{array}{l}\text { Average } \\
2015\end{array}$ \\
\hline Point 3 & 74.9 & 45.3 & 31.4 & 31.2 & 27.8 & 23.3 & 24.7 & 26.9 & 25.3 & 30.6 & 62.6 & 79.0 & 40.27 \\
\hline Rilindja & 51.7 & 54.4 & 38.9 & 26.9 & 24.3 & 20.8 & 35.0 & 37.1 & 32.9 & 36.2 & 65.1 & 83.2 & 60.58 \\
\hline
\end{tabular}

Table 4. Results of $\mathrm{PM}_{2.5},\left(\mu \mathrm{g} / \mathrm{m}^{3}\right)$, average values per month, for 2015. [7]

\begin{tabular}{llllllllllllll} 
Month & Jan. & Feb. & Mar. & Apr. & May & Jun & July & Aug. & Sept. & Octo. & Nov. & Dec. $\begin{array}{l}\text { Average } \\
\mathbf{2 0 1 5}\end{array}$ \\
\hline Point 3 & 70.15 & 34 & 21.81 & 15.42 & 11.49 & 10.79 & 11.4 & 12.0 & 25.3 & 30.6 & 47.2 & 72.0 & 30.18 \\
\hline Rilindja & 44.62 & 34.3 & 25.66 & 16.86 & 9.63 & 10.23 & 13.14 & 22.55 & 14.58 & 21.86 & 54.14 & 68.42 & 27.99
\end{tabular}

According to the data results from Table 1, we can state that maximal values in measuring point 2, was in November 2010, $148.87 \mu \mathrm{g} / \mathrm{m}^{3}$, for $\mathrm{PM}_{2.5}$, and from Table 2, we can also observe that the maximal values in measuring point 3 was also in November 2010, 278.6 $\mu \mathrm{g} / \mathrm{m}^{3}$, for $\mathrm{PM}_{10}$. 
Therefore, air quality in those areas, and measuring points was not satisfactory. Air pollution issues in those areas are high concentrations of particulate matter, and values recorded at this period was exceeding the limits and standards according to the EU. In addition, comparing with the new data from Table 3, and Table 4 we can clearly state that the average values are moderate in 2015 .

Table 5. Results of $\mathrm{PM}_{2.5}$, AQI maximal values per month, Prishtina. Adapted [8]

\begin{tabular}{lllll} 
Year & Month & Day & Hour & AQI \\
\hline 2016 & March & 28 & 0 & 145 \\
\hline 2016 & April & 3 & 21 & 82 \\
\hline 2016 & May & 1 & 7 & 78 \\
\hline 2016 & June & 20 & 22 & 70 \\
\hline 2016 & July & 25 & 7 & 70 \\
\hline 2016 & August & 1 & 2 & 59
\end{tabular}

Table 6. Results of $\mathrm{PM}_{2.5}$, AQI maximal values - last week of March, Prishtina. [8]

\begin{tabular}{lllll} 
Year & Month & Day & Hour & AQI \\
\hline 2016 & Mars & 31 & 22 & 60 \\
\hline 2016 & Mars & 30 & 0 & 75 \\
\hline 2016 & Mars & 29 & 0 & 81 \\
\hline 2016 & Mars & 28 & 0 & 145 \\
\hline 2016 & Mars & 27 & 23 & 144 \\
\hline 2016 & Mars & 26 & 3 & 120 \\
\hline 2016 & Mars & 25 & 23 & 114 \\
\hline 2016 & Mars & 24 & 23 & 76
\end{tabular}

The AQI is an index for reporting daily air quality. Environmental Protection Agency, (EPA), US, calculates the AQI for five major air pollutants regulated by the Clean Air Act: ground-level ozone, particle pollution, carbon monoxide, sulphur dioxide, and nitrogen dioxide. [8] 
Table 7. Values of AQI, the levels of health concern. Adapted [8]

\begin{tabular}{ll} 
Air Quality & Numerical \\
Index & Value AQI \\
Levels of & \\
Health & \\
Concern & \\
\hline
\end{tabular}

\begin{tabular}{lll}
\hline Good & 0 to 50 & $\begin{array}{l}\text { Air quality is considered satisfactory, and air } \\
\text { pollution pose little or no risk. }\end{array}$ \\
\hline Moderate & 51 to 100 & $\begin{array}{l}\text { Air quality is acceptable; however, for some } \\
\text { pollutants there may be a moderate health } \\
\text { concern for a very small number people } \\
\text { who are unusually sensitive to air pollution. }\end{array}$ \\
\hline $\begin{array}{l}\text { Unhealthy } \\
\text { for } \\
\text { Sensitive } \\
\text { Groups }\end{array}$ & 101 to $150 \begin{array}{l}\text { Members of sensitive groups may } \\
\text { experience health effects. The general } \\
\text { public is not likely to be affected. }\end{array}$ \\
\hline Unhealthy & 151 to $200 \begin{array}{l}\text { Everyone may begin to experience health } \\
\text { effects; members of sensitive groups may } \\
\text { experience more serious health effects. }\end{array}$
\end{tabular}

Automobiles, vans, trucks, tractors and buses in Kosovo have raised their quote, approximately 342,000 vehicles, registered in 2015 or 18:46\% more than in 2014, [9]. "These vehicles burn gasoline or diesel fuel in their engines each travelling an average of $16,000 \mathrm{~km} /$ year, at an average fuel economy of $121 / 100 \mathrm{~km}$. This transportation represents a consumption of about 0.5 million tonnes oil/year...Annual Kosovo carbon dioxide amounts, produced from motor vehicle use is estimated at around 0.8 million tonnes or about $15 \%$ of total carbon dioxide $(5.3 \mathrm{Mt}$ ) production in 2003 (both from transport and electricity generation). Motor vehicle greenhouse gas and air pollution emissions is projected to grow up in Kosovo as a result of the increasing number of vehicles"[10]. Therefore, traffic is among the main polluters of air in Prishtina, whereas capital of Kosovo represents foremost this phenomenon and most valued for investigation of urban planning in relation of air pollution. Hence it is expected that adopted measures according to Strategy and Action Plan on Air Quality from Ministry of Environment and Spatial Planning, Department of Environment, in nomenclature T1.3, to carry out some positive impact, "Restricted access to polluted urban areas for vehicles with high pollution ... Determination of space in the city center areas with high pollution from traffic, where access is prohibited"[11]. 
Thus, according to above Strategy and Action Plan, assessment of the costs should be considered that the implementation of measures has its own dynamics, therefore, the implementation of some measures may be extended for a period of 10 years.

"Air pollution is one of the most serious environmental risks. The most recent Global Burden of Disease (GBD) study estimates that air pollution, indoor and outdoor combined, was the cause of 5.5 million premature deaths globally in 2013"[12]. According to the findings of the OECD 2016 for the consequences of outdoor air pollution, air pollution already affects human health, and these impacts are projected to become much more severe in the coming decades. Hence, this is a crucial time and duty to make concrete actions on sensibility and global awareness of air pollution increases in the coming decades. "In absence of additional and more stringent policies, increasing economic activity and energy demand will lead to a significant increase in global emissions of air pollutants, according to projections using the OECD's ENV-Linkages model"[12], findings with crucial key issues:

- $\quad$ The projected increase in concentrations of $\mathrm{PM}_{2.5}$ and ozone will in turn lead to substantial effects on the economy ... global air pollution-related healthcare costs are projected to increase from USD 21 billion (using constant 2010 USD and PPP exchange rates) in 2015 to USD 176 billion 2005 in 2060. By 2060, the annual number of lost working days, which affect labour productivity, are projected to reach 3.7 billion (currently around 1.2 billion) at the global level."[12].

- "The most dangerous consequences from outdoor air pollution are related to the number of premature deaths. This report projects an increase in the number of premature deaths due to outdoor air pollution from approximately 3 million people in 2010, in line with the latest Global Burden of Disease estimates, to 6-9 million annually in 2060. A large number of deaths occur in densely populated regions with high concentrations of $\mathrm{PM}_{2.5}{ }^{\prime[}[12]$.

Therefore, according to this findings, air pollution will cause six to nine million premature deaths per year by 2060 , compared with three million in 2010 . With this prediction at maximal value of nine million, this means, that one person will perish every three to four seconds annually, related to the diagnostic of premature deaths. 


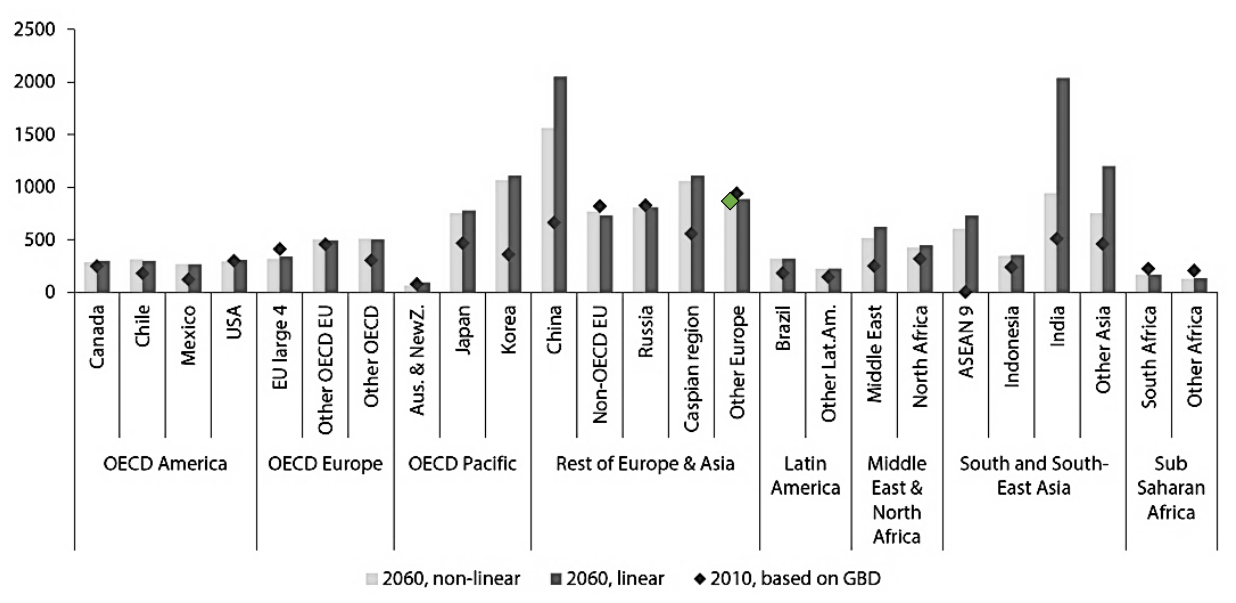

Figure 3. Premature deaths from exposure to particulate matter and ozone. Projected number of deaths caused by outdoor air pollution per year per million people. [12].

Table 8. Measured values for $\mathrm{PM}_{\mathbf{x x}}$ in downtown, Rilindja, Prishtina. Adapted [13].

\begin{tabular}{|c|c|c|c|c|c|}
\hline $\begin{array}{l}\text { Month } \\
\text { PM }_{10}\end{array}$ & $\begin{array}{c}\text { The } \\
\text { maximum } \\
\text { daily } \\
\text { average } \\
\left(\mu \mathrm{g} / \mathrm{m}^{3}\right)\end{array}$ & $\begin{array}{c}\text { Date of } \\
\text { maximum } \\
\text { value }\end{array}$ & $\begin{array}{l}\text { Month } \\
\mathrm{PM}_{2.5}\end{array}$ & $\begin{array}{l}\text { The } \\
\text { maximum } \\
\text { amount for } \\
\text { an hour } \\
\left(\mu \mathrm{g} / \mathrm{m}^{3}\right)\end{array}$ & $\begin{array}{c}\text { Date of } \\
\text { maximum } \\
\text { value }\end{array}$ \\
\hline January & 403.51 & 13.01 .2015 & January & 317.77 & 14.01 .2015 \\
\hline February & 109 & 20.02 .2015 & February & 189.2 & 19.02 .2015 \\
\hline March & 77.86 & 21.03 .2015 & March & 54.71 & 15.03 .2015 \\
\hline April & 66.58 & 09.04 .2015 & April & 110 & 10.04 .2015 \\
\hline May & 61.45 & 30.05 .2015 & May & 50.64 & 15.05 .2015 \\
\hline June & 61 & 30.06 .2015 & June & 53.0 & 10.06 .2015 \\
\hline July & 44.8 & 05.07 .2015 & July & 20.3 & 28.07.2015 \\
\hline August & 48.9 & 12.08 .2015 & August & 22.7 & 03.08 .2015 \\
\hline September & 51.6 & 18.12 .2015 & September & 51.6 & 18.9 .2015 \\
\hline October & 82.1 & 26.10 .2015 & October & 82. & 26.10 .2015 \\
\hline November & 142.0 & 05.12 .2015 & November & 102.3 & 08.11 .2015 \\
\hline December & 158.8 & 15.12 .2015 & December & 159.0 & 15.12 .2015 \\
\hline
\end{tabular}

According to directive for air quality (2008/50/EC) during a year are allowed 35 days to exceed the standard values for $\mathrm{PM}_{\mathbf{1 0}}$. Based on this study [13], there was 74 days which exceeded the values of $\mathrm{PM}_{10}$, indicated the amount of pollution from particulate matter, with greatest excesses months: January, February, November and December. Assessment of $\mathrm{PM}_{2.5}$ concentrations in compliance with air quality standards are based on the annual 
value. In analysing for dust pollution, standard values have had been exceeded, where allowed rate is $25 \mu \mathrm{g} / \mathrm{m}^{3}$ during the year, with greatest excesses months: January, February, November and December, [13].

\section{The fast growing Prishtina - Case Study}

Spatial development of Pristina, in the past has not been the objective of research in professional and scientific programme. Chronologically, it's important to evident the actions of spatial arrangements of urban planning, city of Prishtina;

- Pristina development plan, (1937). Included the area of 192.72 ha and was programed for population of 16,000 inhabitants.

- The second development plan, (1948). No trace of the existence of this documentation, nor to its basic parameters.

- General urban plan, (1953). The timeline of spatial plan was up to 1980, and the town was planned for 50,000 inhabitants in the area of 950 ha.

- Directive plan for traffic and dedication of city zones, (1967). With action plan for 100,000 inhabitants and 1950 ha of area examined

- In 1969, the Directive plan for traffic and dedication of city zones it was replaced by General urban plan of Prishtina.

- The overall urban plan and spatial development plan in 1988 was approved for the timeline to year 2000, considering for 225,000 inhabitants, area of 4335 ha [14].
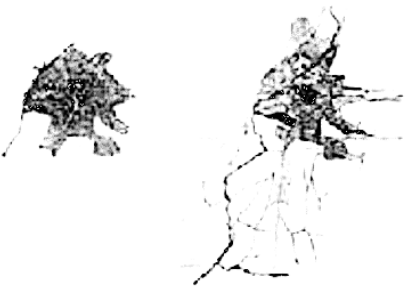

1937

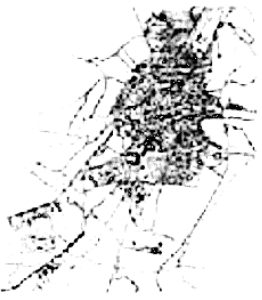

1960

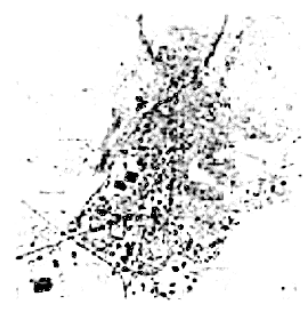

1999

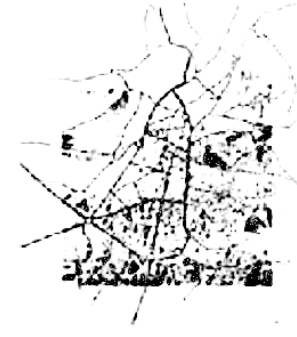

2004

Figure 4. Historical development of the city of Prishtina [15].

During 2005, the Municipality of Pristina have concluded that it is necessary to build a public parking garage in the city, containing approximately 1,000 parking spaces. This decision was an old idea, with its genesis from 80 's-90's, on attempt to solve the problem of the traffic, for the city had. However, the last two decades, starting from the first idea to build a public parking garage to the current situation, and the implementation of the 
project, have brought a variety of phenomenon's, primarily demographic, social, environmental and political. The socio-demographic and spatial boom in 2000, the process of uncontrolled growth of the city, is a result and characteristics of major cities after major events, like war for example. "According to the estimate of the OSCE (Extrapolated level growth of former population in Kosovo 2\%/yr.), city of Prishtina in 2000 had 545,477 inhabitants"[14]. Thus, there are persistent institutional activities and municipal actions on the strategic development plans for the city. The new millennium began with crucial activities for Pristina, in terms of demographic and spatial development. The city is experiencing a multidimensional change in all possible fields. Being the capital city of Kosovo, in a very short time the population of Prishtina has nearly doubled, adding every day approximately another $30 \%$ of the population coming here for work, or possible settlement and migration. Prishtina has never in its history had a tramcar or other similar affordable public transport.

The city before 2000, had reached the maximal growth of population in 1991, approximately 200,000 inhabitants, according to registration. The traffic worked quite well with the existing infrastructure, and was not such a big problem for the community until the number of motor vehicles were increased at the beginning of the new millennium. Actually number of vehicles registered in Prishtina are approximately 50.965, [16].
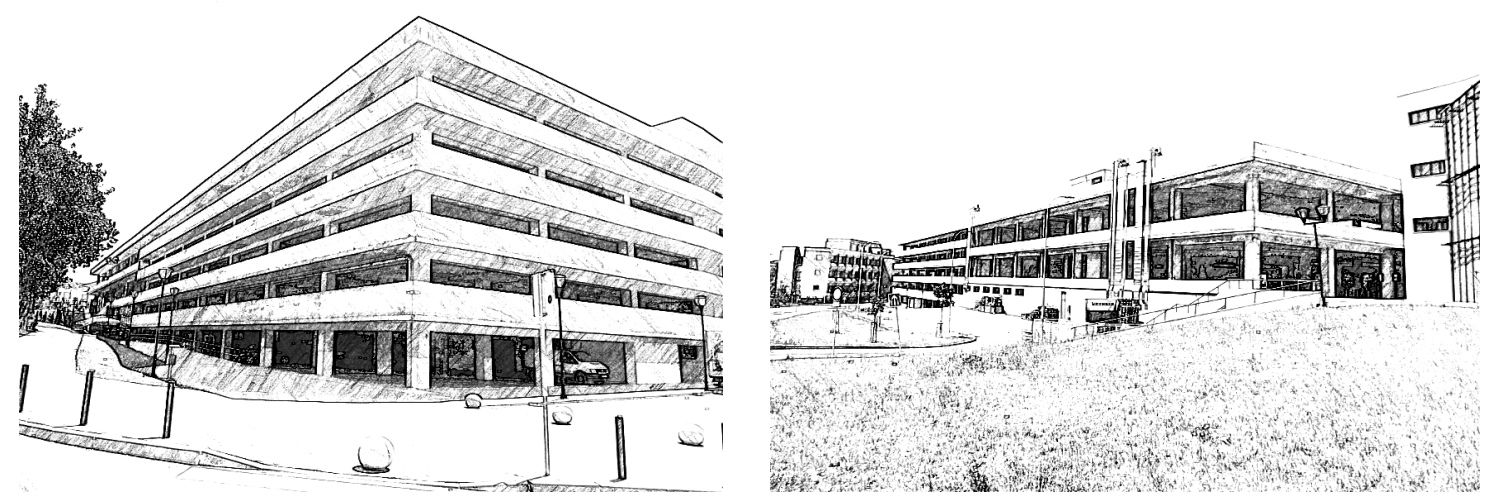

Figure 5. First City Public Parking Garage, Prishtina. [Source: Authors, 2016]

The planning department of the municipality of Prishtina came up with different ideas and concepts in terms of resolving or addressing traffic problem, by converting existing roads into one-way drive. However, with insufficient funding the idea became part of the system 
"vicious circle". The city of Prishtina always lacked parking places, as such parking garages were more than needed. Moreover, there were too many conceptual challenges, and in 2005 the Department of Urban Planning and Construction of the Municipality of Prishtina, decided to bid an open public parking garage, located near the campus of the Clinical Hospital Centre of Prishtina.

\section{RESULTS and DISCUSSION}

In trend of community services, it is normally expected to have optimal reserved parking spaces for patients and visitors at the hospital centre. However, this space is dimensionally restricted and generally parking time is limited and very expensive. Regarding to the urban composition structures near the $\mathrm{CHCP}$, a difficult urban environment and land use situation has been created. In comparison to other cities of Kosovo, Prishtina does not have a city hospital. Because of the specific social, cultural and health situations, the Clinical Hospital Centre of Prishtina is the only institution offering secondary and tertiary medical care.

Table 9. City of Prishtina, services of CHCP during 2014. Adapted [17].

\begin{tabular}{lllll} 
CHCP & $\begin{array}{l}\text { Service } \\
\text { Days }\end{array}$ & $\begin{array}{l}\text { Patients } \\
\text { in Clinic }\end{array}$ & $\begin{array}{l}\text { Diagnostic } \\
\text { Visits }\end{array}$ & $\begin{array}{l}\text { Special } \\
\text { Services }\end{array}$ \\
\hline Gynecology Clinic & 83,099 & 34,146 & 5,483 & 2,139 \\
\hline Infectious Clinic & 34,162 & 3,074 & 1,964 & 1,214 \\
\hline Pulmonology Clinic & 21,590 & 1,446 & 634 & - \\
\hline Cardiology Clinic & 17,260 & 3,260 & 19,886 & 61,461 \\
\hline Pediatric Clinic & 59,660 & 6,666 & - & 8,235 \\
\hline Neonatology Clinic & 47,154 & 1,148 & 3,821 & - \\
\hline Children Surgery Clinic & 4,754 & 1,614 & - & 2,424
\end{tabular}

In Table 9 are presented data for primarily health vulnerable populations: Infants, children, pregnant women, patients with lung problems, patients with cardiac problems and hazard from possible infectious disease. Hence, in this context "Motor vehicles emit at least 40 different air pollutants, usually concentrated within 100-500 metres of freeways and busy roadways, and research points to a need for increased awareness of the public health concerns associated with roadway proximity in creating land-use policy, building design and environmental/air quality management programs"[18]. Carbon monoxide is an atmospheric pollutant, environmentally this pollutant is produced on the incomplete 
combustion of carbon containing fuel, such as gasoline. Largest source of carbon monoxide are vehicle emissions. Carbon monoxide have specific features to be associated with blood hemoglobin and thus to form Carboxyhemoglobin, and this is a stable complex of carbon monoxide and hemoglobin which prevents the transport of oxygen in the body? "Hemoglobin binds with carbon monoxide 200-250 times more readily than with oxygen"[19].

"From the data provided by the Ministry of Internal Affairs, in 2014, in Kosovo were a total of 286.505 vehicles registered. Of them, only 111.855 are produced from 2000 and onwards, the others, or $61 \%$ of vehicles are produced between 1942-1999. In general, it appears that the average age of the registered vehicles in 2014 was 18.1 years"[20]. According to the conferred data it can be concluded that Prishtina is polluted regarding the suspended fine particles $\mathrm{PM}_{10}-\mathrm{PM}_{2.5}$. In general, Prishtina is heavily polluted due to its geomorphic position relative to the major polluters, power plants Kosovo A and B. At the same time, pollution was supported by heavy traffic, and prevailing winds which increase and distribute more this pollution in certain directions. However, according to this study, chosen location for building first public parking garage even more contributes with air pollution to campus of Clinical Hospital Centre in Prishtina. Therefore, when CHCP lacks a real space for the evolutive expansion of medical services. When there was a need for expanding the capacities of the campus, such as the cardiovascular clinic, there was a lack of space. The impact of urban growth on demographic changes and traffic problems in the city of Prishtina are very serious. In this environmental situation, composition of urban structure on campus of Clinical Hospital Centre are wide open and all the actual buildings are naturally ventilated thru old windows. Thus, every single patient room must be naturally ventilated, especially those in mentioned above clinics in all seasons, heavily in summer because of heat. Regarding to the wind direction and near distance of parking garage it is expected that air pollution have to affect more campus and clinics buildings. According to the study "the number of high-traffic roads within a 250-m radius of a location, the presence of a major road within a distance of $50 \mathrm{~m}$, the density of buildings within a 300-m radius and an indicator for the region of the country were used in the model ... The finding of a positive association between air pollution and objectively measured sensitization to common allergens, supports the findings of subjectively reported symptoms"[2]. "In Oakland California, school children at schools in proximity to high volume roadways experienced more asthma and bronchitis symptoms. In Southern California, School 
Children living within $75 \mathrm{~m}$ of a major road was associated with an increased risk of lifetime asthma, prevalent asthma, and wheeze. In 12 southern California communities, children who lived with 500 meters of a freeway had reduced growth in lung capacity relate to those living greater than 1500 from the freeway. In a study of German adults, residence within 200 meters of a major road predicted coronary artery calcification. Residence within 150 meters of a major road predicted manifest coronary heart disease"[21]. Clinical Hospital Centre of Pristina every annual year had nearly half a million of patient treatment days. However, the average of occupied beds annually is more than 1000. Based on this data it can be concluded without doubt that the air quality will be even more endangered for the patients, staff and visitors in the near future. The need for parking spaces and public parking garages in Prishtina are very immediate, moreover, the sustainable urban and architectural design is facing major challenges as a result of many contemporary factors: heavy traffic, air pollution, life style, economy and the trend of developed technology. On the other hand, Kosovo is also participating in global trends, a process by which regional economies, societies and cultures are integrated through a global network of political ideas, communication, transport and market sharing. According to the data from the Kosovo police, "Pristina with the current infrastructure cannot be withstood a flow of 120,000 vehicles within 24 hours, especially in the hours when the population goes and comes from work, school and other needs such as hospitals, various institutions"[22], emphasizing that $80 \%$ of them are old and thus burn fuels in an ineffective way. It is evident that these moving vehicles need a parking place! Actually, the planning department of the municipality of Prishtina are on actions to reform the public traffic, moreover those actions go further to find a solution of parking places according to the pattern of the City Zagreb. According to the Strategy and Action Plan on Air Quality, sponsored by Ministry of Environment and Spatial Planning, Department of Environment, in Measures for reduction of air pollution from transport, in section T3.1 "Improving the legal framework of planning, seeking an urban transport plan for the largest cities in Kosovo Administrative capacity building at municipal level to ensure that the demands for motor traffic is minimized during the planning of new buildings, commercial buildings, commercial facilities"[11], with a high priority and key responsible actors: Municipality of Prishtina, MESP and MI. There was a modest specific actions, especially after approving this action plan, real challenges were and actually are, implementing those measures. Hence, regarding to this case study, there was no reconsideration even to change the architectural function of public parking garage. Rapid continuing to build this structure are seen in 2014, after a considerate 
timeline pause, persisting to accept that time and health awareness are changed locally, and globally. Air pollution is a global issue, therefore, can't be addressed only locally, moreover local actions are irreplaceable and crucially necessary, resulting to make a better living, a better quality of life and healthier communities. In this paper we argue that the chosen location for public parking garage may not be the most fruitful approach to urban design.

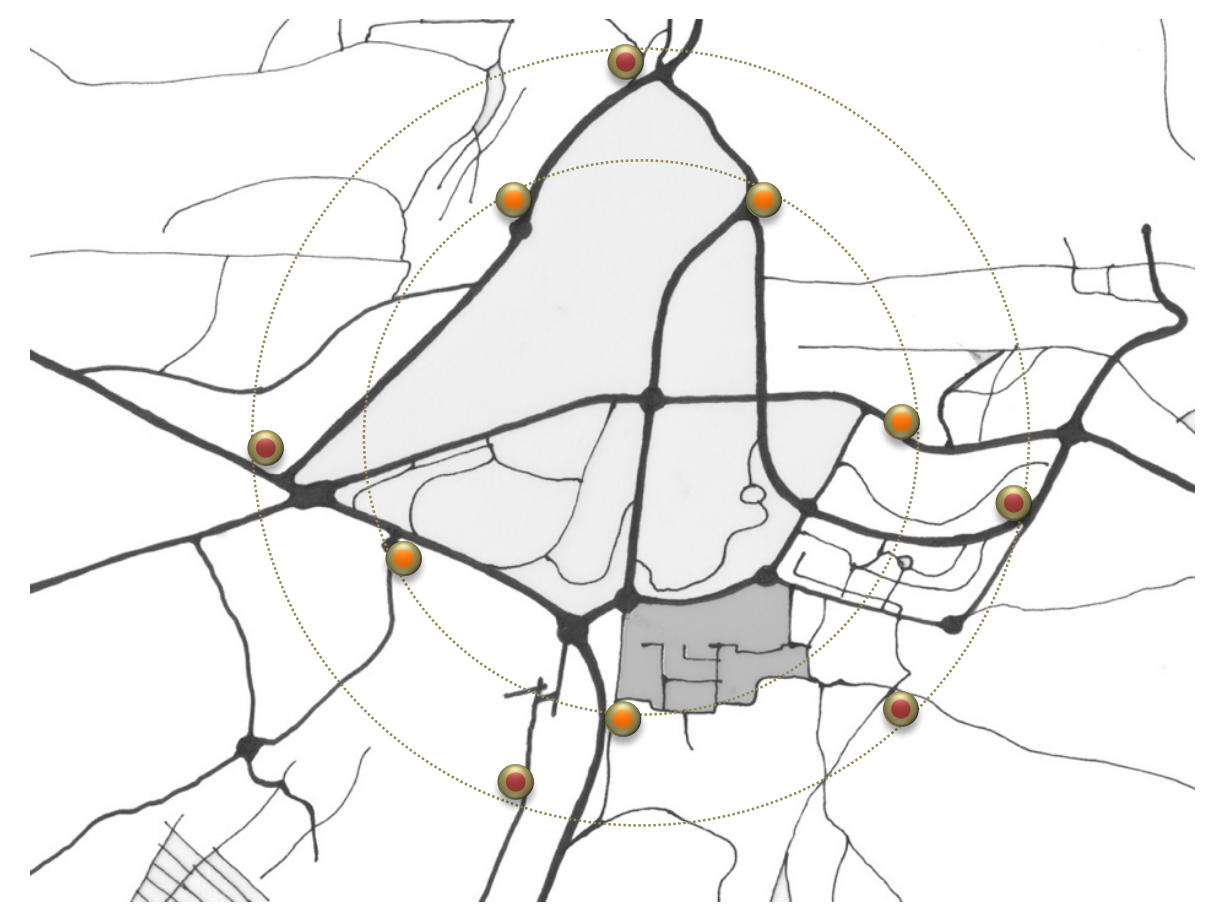

Figure 6. Preferred urban concept, parking garages located in primary and secondary urban ring. [Source: Authors, 2016]

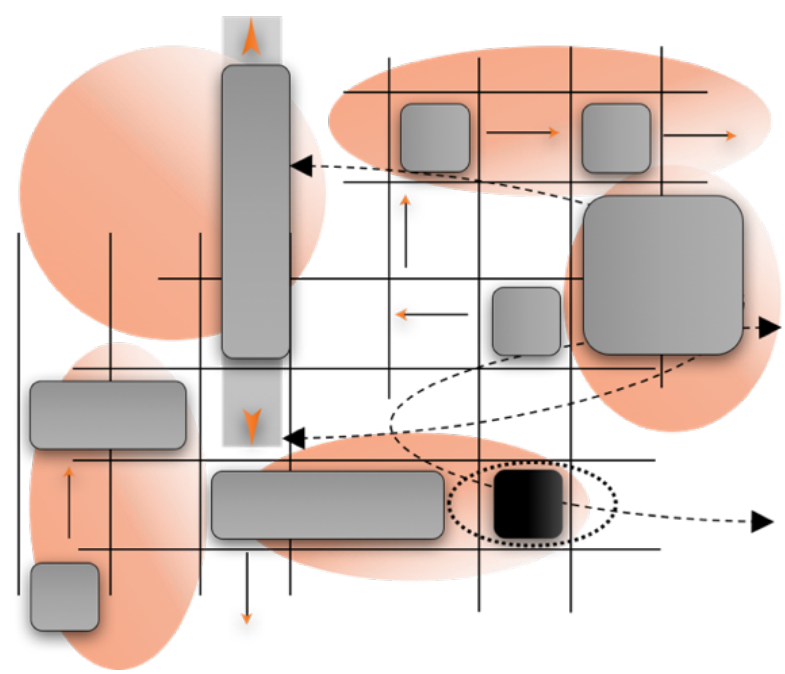

Figure 7. Public parking garage to serve many urban blocks. [Source: Authors, 2016] 
As we can see in Figure 6, there is a conceptual urban strategy to offer a variety of public parking garages, instead only one and big architectural structure, also there is need that those type of buildings blend in within an urban composition, preferably incorporated or isolated with a cultivated vegetation. As from urban planning concepts we stand that in those situations, a more suitable are hybrid structures, moreover, parking garages can be realized underground with a closed type of garage. Naturally, those types of architecture structures demand a heavy mechanical ventilation, always preferring to implement a new nanotechnology filters as a contemporary technology answer regarding to air pollution. Prishtina like the other cities must consider to implement a strategy of underground building structures as a whole functional urban system, actually it is with ease helped by new developed technologies. Kosovo has only $10,908 \mathrm{~km}^{2}$, therefore we must consider other options of spatial planning, including underground. In the context of chosen urban location for parking garages, we must first conceptually consider:

- Avoiding possible locations for parking garages from built urban structures like: Hospitals, day care facilities, schools, housing and residences.

- Special consideration should be given that those buildings serve many urban blocs instead of one zone, avoiding locations or situations where it's difficult or too far to be reached from inhabitants.

- Indwelling locally and blend in to existing urban composition.

Considering the economics of those type of buildings and emanation of air pollution, those structures are firmly built for many decades, hence, we have to be extra alert and certain for possible locations to build. Moreover, in this case study, chosen location of public parking garage are example of inappropriate indwelling locally and blend in to existing urban composition, a position in mid between primary school "Hasan Prishtina", with 1975 children daily frequented, and Clinical Hospital Centre of Prishtina [23]. "Roadside vegetation barriers have shown the potential to reduce near-road air pollution concentrations; however, the characteristics of these barriers needed to ensure pollution reductions are not well understood ... Two potentially viable design options are revealed: a) a wide vegetation barrier with high Leaf Area Density (LAD), and b) vegetation-solid barrier combinations, i.e., planting trees next to a solid barrier. Both designs reduce downwind particle concentrations significantly"[24]. According to the study, "the tree species used for the GAIA-urban forestation project were selected, starting from the green Regulations of the City of Bologna and evaluating important factors such as the potential 
for absorption of pollutants $\left(\mathrm{CO}_{2}\right.$ and $\left.\mathrm{PM}_{10}\right)$, the release of substances volatile and the allergenic specific factors, the first 24 most suitable species have been identified to fulfil this function"[25]. "There is a considerable potential to further develop the beneficial use of vegetation to promote urban environmental quality and citizen health... Trees and shrubs were compared for PM accumulation on the surface"[26].

Table 10. Trees that can reduce air pollution. Adapted [25].

\begin{tabular}{|c|c|c|c|c|c|c|c|}
\hline Tree & $\begin{array}{l}\text { Height } \\
\text { m' }^{\prime}\end{array}$ & $\begin{array}{l}\mathrm{CO}_{2} \\
\text { stored } \\
30 / y r . \\
\text { City } \\
\text { (kg.) }\end{array}$ & $\begin{array}{l}\mathrm{CO}_{2} \\
\text { stored } \\
50 / \text { yr. } \\
\text { Park } \\
\text { (kg.) }\end{array}$ & VOC & $\begin{array}{l}\text { Ozone } \\
\text { format. } \\
\text { potential }\end{array}$ & $\begin{array}{l}\text { Potential } \\
\text { for } \\
\text { absorption } \\
\text { of gaseous } \\
\text { pollutants }\end{array}$ & $\begin{array}{l}\text { Potential } \\
\text { for } \\
\text { capturing } \\
\text { dust }\end{array}$ \\
\hline & & & & \multicolumn{4}{|c|}{ Ability to environmental mitigation potential } \\
\hline Acer Platanoides & 25 & 4807 & 6601 & Low & Low & High & Med. \\
\hline Tilia Platyphyllos & $>25$ & 3660 & 5070 & Med. & Aver. & High & High \\
\hline Tilia Cordata & $15-25$ & 3660 & 5070 & Low & Low & High & High \\
\hline
\end{tabular}

Urban Access Restrictions, actually many restrictions related to air pollution are in law guidelines throughout Europe. "The most prominent example of local bans on high emitters are Low Emission Zones (LEZ). Local LEZ's can be an effective way of reducing particulate matter $\left(\mathrm{PM}_{10}\right)$ and soot emissions. An increasing number of cities are implementing LEZs...Vehicles are classified based on their EURO standards"[27].

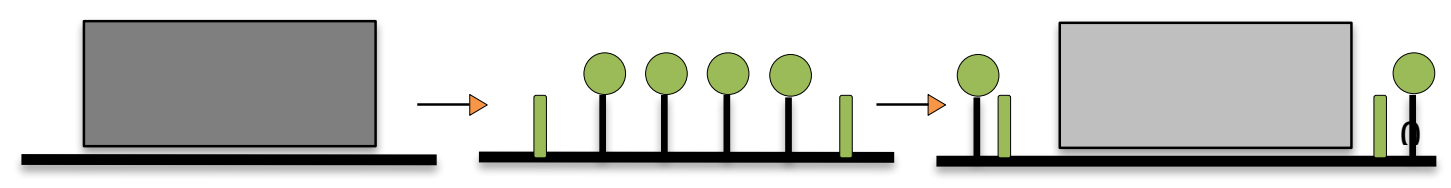

Figure 8. Model a). Aboveground public parking garage, with vegetation barriers. [Source: Authors, 2016]

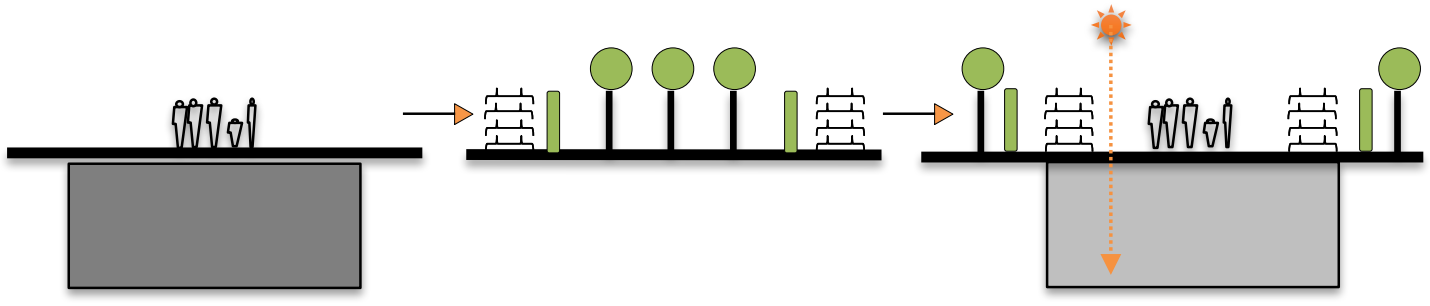

Figure 9. Model b). Underground public parking garage, with filters, vegetation barriers and with more bringing natural light. A more expensive solution. [Source: Authors, 2016] 
Potential measures for a healthier environment in public parking garages, with underground building concept, include a diversity of system filters which can offer all in one solution, "Where proximity to traffic is unavoidable, the use of high-efficiency particulate air (HEPA) filters is recommended to reduce exposure to particulate air pollution"[18].

"Tri-Mer Ceramic Catalyst Filter Systems, is system for removing particulate $\mathrm{PM}_{\mathbf{x x}}, \mathrm{SO}_{2}$, $\mathrm{HCl}$, mercury and heavy metals. Simultaneously, the ceramic catalyst filters destroy NOx, cement organic HAPs, and dioxins"[28].

\section{CONCLUSION}

Air pollution is a global issue, therefore, can't be addressed only locally, moreover local actions are irreplaceable and crucially necessary. The current degraded state of environment and urban fabric requires specific responsibilities and activities, especially when the state is directly linked to the quality of life and public health. Implementing approved measures according to the Strategy and Action Plan on Air Quality, by MESP must be immediate and irreplaceable policy action for healthier Kosovo. Hence, according to the results of this study, we prefer urban pattern where parking garages can be certainly located in primary and secondary urban ring. According to the data for air pollution in the actual location, and distance of parking garage to CHCP campus, it is expected that air pollution has to affect more campus and patients of clinics. Moreover, as a sustainable strategy, imperative can be a reconsideration to eventually change the architectural function of public parking garage.

Therefore, where proximity to traffic is unavoidable, and from built urban structures like: hospitals, day care facilities and schools, we consider a more appropriate are urban models of underground public parking garages, with filters as a wide system, and vegetation barriers, but they represent a more expensive solution. If located and designed well, structured multiuse parking garages can be more than just parking places. Based on results of air pollution and urban planning concept presented in this paper, location for the first public parking garage of Prishtina was inadequate, as pattern for future public parking garages. The potential future work and research will be more focused on the transdisciplinary process of design as an environmental municipal strategy, implementing optimized patterns and performance of hybrid structures. 


\section{NOMENCLATURE}

$\begin{array}{ll}A Q I & \text { Air quality index } \\ C H C P & \text { Clinical Hospital Centre of Prishtina } \\ E P A & \text { Environmental Protection Agency, US. } \\ G B D & \text { Global Burden of Disease } \\ L A D & \text { Leaf Area Density } \\ L E Z & \text { Low Emission Zones } \\ M E S P & \text { Ministry of Environment and Spatial Planning } \\ M E M & \text { Ministry of Energy and Mining } \\ M I & \text { Ministry of Infrastructure } \\ \text { OECD } & \text { Organisation for Economic Co-operation and Development } \\ \text { OSCE } & \text { Organization for Security and Co-operation in Europe } \\ C O_{2} & \text { Carbon dioxide } \\ C O & \text { Carbon monoxide } \\ \text { Metric ton } & \\ P M_{x x} & \text { Particulate matter } \quad\left[\mu \mathrm{Mt} / \mathrm{m}^{3}\right] \\ C u b i c \text { metre } & \\ \text { VOC } & \text { Volatile organic compound }\end{array}$

\section{Greek letters}

$\mu \quad$ micro $\quad$ [0.000001]

\section{REFERENCES}

1. WHO, Europe, Krzyzanowski et al., Health effects of transport-related air pollution. (C) World Health Organization. Copenhagen, Denmark, 2005.

2. Brauer, M. et al., Air pollution and development of asthma, allergy and infections in a birth cohort. CERS Journals Ltd 2007, 2007. DOI: 10.1183/09031936.00083406

3. Kabashi, S. et al., Effects of Kosovo's energy use scenarios and associated gas emissions on its climate change and sustainable development. Applied Energy Volume 88, Issue 2, February 2011, Pages 473-478, 2011. http://dx.doi.org/10.1016/j.apenergy.2010.06.023

4. http://enrin.grida.no/htmls/kosovo/SoE/energy.htm. [Accessed: 10-August-2016]

5. Ministry of Energy and Mining (MEM). < http://www.ks-gov.net $/ \mathrm{mem}>$. [Accessed: 10-August-2016]

6. Tahirsylaj, and Latifi., Quality of Air in Urban and suburban Areas of the Prishtina. Ohrid, FYROM, Macedonia. pp. 1-7, 2011. [Accessed: 11-August-2016] $<$ http://s3.amazonaws.com/zanran storage/balwois.com/ContentPages/78546993.pdf, $>$

7. Ministry of Environment and Spatial Planning., Summary report, air condition in 2015. 2016. < http://www.ammk-rks.net/?page=1,21> [Accessed: 11-August-2016]

8. Environmental Protection Agency, [US]. AirNow Department of State. Kosovo, Pristina City. [Accessed: 10-August-2016] $<$ https://airnow.gov/index.cfm?action=airnow.global summary\#Kosovo\$Pristina $>$

9. Kosovo Agency of Statistics., Transport and telecommunications statistics TM2-2016, 2016. < http://ask.rks-gov.net/sq/transporti > [Accessed: 12-August-2016]

10. Kabashi, S. et al., Greenhouse gas and air pollution emissions and options for reducing from the Kosovo transportation sector-dynamic modelling. Management of Environmental Quality: An International Journal Vol. 22 No. 1, 2011 pp. 72-88 (C) Emerald Group Publishing Limited 1477-7835, 2011. DOI 10.1108/14777831111098499 
11. Ministry of Environment and Spatial Planning., Strategy and Action Plan on Air Quality. Kosovo, 2011. $\quad<$ http://www.kryeministriks.net/repository/docs/Strategy and Action Plan on Air Quality.pdf $>$ [Accessed: 19August-2016]

12. OECD., The economic consequences of outdoor air pollution, OECD Publishing, Paris. 2016. [Accessed: 19-August-2016] <https://www.oecd.org/environment/indicatorsmodelling-outlooks/Policy-Highlights-Economic-consequences-of-outdoor-air-pollutionweb.pdf $>$

13. Qorraj, E., Air pollution from motor vehicles in the city of Prishtina and effects on traffic safety. University of Prishtina. 2016. Hydrometeorology Institute of Kosova. $<$ http://fim.uni-pr.edu/getattachment/dca85ad3-515d-402d-9dfc-f0333604359a/5 --NDOTJA-E-AJRIT-NGA-AUTOMJETET-MOTORIKE-NE-QYTE.aspx $>$

[Accessed: 19-August-2016]

14. Municipal Assembly of Prishtina., Strategic Plan, Urban Development of Prishtina 2004-2020. Prishtina, 2004. Accessed: August 2016. http://www.bp-home.com/about/plani_urbanistik/plani_strategjik.pdf $>$

15. Municipal Assembly of Prishtina, (2013). Strategic environmental assessment of urban development plan pristina 2013-2023. Prishtina. https://kk.rksgov.net/prishtina/getattachment/Sherbime/Tema/Vleresimet-e-planit/Vleresimi-i-planitzhvillimor-komunal-prishtine.pdf.aspx $>$ [Accessed: 19-August-2016]

16. EuroLab., Kosovar Vehicle Centre. Kosova, 2016.

17. Kosovo Agency of Statistics., Health Statistics 2014, 2015. $<$ http://ask.rks-gov.net/sq/shendetsia $>$. [Accessed: 19-August-2016]

18. British Columbia Ministry of Environment., Develop with Care 2012: Environmental Guidelines for Urban and Rural Land Development in British Columbia. Supporting Information - Air Quality. University of British Columbia, 2012. $<\underline{\text { http://www.env.gov.bc.ca/wld/documents/bmp/devwithcare/DWC-Air-Quality.pdf }>}$ [Accessed: 19-August-2016]

19. Jacquez, J., Respiratory Physiology. McGraw-Hill. pp. 156-175, 1979.

20. GAP Institute., The economy of cars in Kosovo. 2015. [Accessed: 20-August-2016] $<$ http://www.institutigap.org/documents/40449 EconomyofCars.pdf $>$

21. Bhatia, R. and Rivard, T., Developing Regulatory Approaches for Traffic - related Air Pollution Hot Spots. San Francisco Department of Public Health. 2008. http://www.baaqmd.gov/ /media/files/planning-and-research/care-program/task-forcemeetings/091708-tf/20080917 tf sfdphroadway.pdf?la=en $>$

[Accessed: 20-August-2016]

22. Haziraj, A. F., Media officer - Regional Police Directorate in Pristina, 2013. $<$ http://www.arkivalajmeve.com/240-mije-vetura-ne-ldquorksrdquo-100-mije-vetem-nePrishtine.1047418855/> [Accessed: 22-August-2016]

23. Municipality of Prishtina, Directorate of Education, Information's 2015/2016. https://kk.rksgov.net/prishtina/getattachment/Municipality/Departments/Arsimit/Raportet/Informata-e-suksesit-per-gjysmevjetorine-dyte-2015-16.pdf.aspx , pp. 15-18.

[Accessed: 25-August-2016]

24. Tong et al., Roadside vegetation barrier designs to mitigate near-road air pollution impacts. C 2015 Elsevier. 2015. [Accessed: 25-August-2016] http://dx.doi.org/10.1016/j.scitotenv.2015.09.067

25. GAIA., Institute of Biometeorology, Bolonia. Baraldi, R., European Life+ project. Trees that can reduce air pollution. 2016. $<\underline{\text { http://lifegaia.eu/ }>>}$

[Accessed: 24-August-2016] 
26. Saebo, A. et al., S.W. Characterization of urban trees and shrubs for particulate deposition, carbon sequestration and BVOC emissions, 2013. Acta Hortic. 990, 509-517. DOI: 10.17660/ActaHortic.2013.990.66

27. Clean Air., Local bans of high emitters, 2015. < http://www.cleanair-europe.org/ > [Accessed: 24-August-2016]

28. Tri-Mer Corp.C, Ceramic Catalyst Filter system, 2016.

http://www.tri-mer.com/pdf-

files/Ceramic $\% 20$ Catalytic $\% 20$ Filter $\% 20$ Systems $\% 20$ Boiler $\% 20$ MACT $\% 20$ CISWI $\% 20$ Cement\%20NESHAP.pdf $>$ [Accessed: 24-August-2016] 